\title{
PENGARUH PENAMBAHAN TEPUNG TOMAT (Solanum lycopersicum $l$ ) TERHADAP KUALITIAS INTERNAL TELUR AYAM RAS
}

\author{
Vrilly E. Timbuleng*, Jacqueline T. Laihad**, Jein. R. Leke**, Siane C. Rimbing** \\ Fakultas Peternakan Universitas Sam Ratulangi, Manado
}

\begin{abstract}
ABSTRAK
Penelitian ini betujuan untuk mengetahui sejauh mana penambahan tepung tomat memberikan pengaruh terhadap kualitas internal telur ayam ras. Materi yang digunakan dalam penelitian ini adalah 100 ekor ayam ras petelur berumur 36 minggu dengan perlakuan yang diberikan yaitu P0 : ransum basal tanpa tepung tomat; $\mathrm{P} 1$ : ransum basal $98 \%+2 \%$ tepung tomat; P2: ransum basal $96 \%+4 \%$ tepung tomat; P3: ransum basal 94\% $+6 \%$ tepung tomat; P4: ransum basal $92 \%+8 \%$ tepung tomat. Rancangan yang digunakan adalah Rancangan Acak Lengkap (RAL) dengan 5 perlakuan dan 5 ulangan dengan masing-masing perlakuan diisi dengan 4 ekor ayam sehingga terdapat 100 ekor ayam, kemudian dilanjutkan dengan uji jarak berganda Duncan. Variabel yang diamati selama penelitian meliputi indeks kuning telur, warna kuning telur dan haugh unit (HU). Hasil penelitian menunjukkan bahwa penambahan tepung tomat dalam ransum tidak memberikan pengaruh nyata $(\mathrm{P}>0,05)$ terhadap indeks kuning telur dan haugh unit (HU), namun memberikan pengaruh sangat nyata $(\mathrm{P}<0,01)$ terhadap warna kuning telur. Berdasarkan hasil penelitian yang diperoleh, maka dapat disimpulkan bahwa penambahan tepung tomat dalam pakan sebanyak $8 \%$ memberikan respons yang baik terhadap indeks kuning telur, haugh unit, dan warna kuning telur ayam ras petelur.
\end{abstract}

Kata kunci :Ayam Petelur, Kualitas Internal Telur, Tepung Tomat.

\footnotetext{
* Alumni Fakultas Peternakan

** Jurusan Produksi Ternak
}

\begin{abstract}
EFFECT OF TOMATOES STARCH (Solanum lycopersicum l) ON INTERNAL EGG QUALITY OF LAYING CHICKEN. This research has been done to determine the effect of tomatoes starch on the internal egg quality of laying chicken. The material used in this study was a 100 laying hens aged 36 weeks with the following treatments P0: basal ration without tomatoes startch; $\mathrm{P} 1$ : $98 \%$ of basal ration $+2 \%$ of tomatoes starch: P2; $96 \%$ of basal ration $+4 \%$ tomatoes starch; $\mathrm{P} 3$ : $94 \%$ of basal ration $+6 \%$ of tomatoes starch; $\mathrm{P} 4$ : $92 \%$ of basal ration $+8 \%$ of tomatoes starch. Research design used was the completely randomized design (CRD) with 5 treatment and 5 replications. Duncan's multiple range test was used for further test. Variables were observed during the study include egg yolk index, yolk color, and Haugh unit (HU). The results showed that the addition of tomatoes in the diet has no significant effect $(\mathrm{P}>0.05)$ on egg yolk index and haugh units (HU), but highly significant effect $(\mathrm{P}<0,01)$ against the color of egg yolks. Based on the research results obtained, it can be concluded that the addition of tomatoes starch in ration as much as $8 \%$ will provide a good response to the effect of egg yolk index, Haug units (HU), and yellow egg of laying chicken.
\end{abstract}

Keywords :Laying Chicken, Internal Egg Quality, Tomatoes Starch.

\section{PENDAHULUAN}

Kebutuhan protein masyarakat masih sangat bergantung pada produk peternakan. 
Protein merupakan salah satu zat makanan yang diperlukan oleh manusia agar bisa bertumbuh kembang dan tetap sehat. Fungsi protein antara lain untuk membuat dan memperbaiki sel-sel tubuh yang rusak. Dengan demikian, bahan makanan sumber protein harus tersedia dalam menu makanan sehari- hari, agar tubuh kita memperoleh asupan gizi yang seimbang. Meningkatnya kebutuhan protein hewani merupakan akibat dari pertambahan penduduk dan meningkatnya kesadaran masyarakat akan pentingnya protein hewani bagi kesehatan masyarakat. Salah satu produk peternakan yang tentunya tidak asing lagi bagi kebanyakan orang adalah telur.

Salah satu produk pilihan yang cukup murah dan mudah didapat dan selalu tersedia setiap saat tanpa mengenal musim (Medhy, 2008). Telur adalah salah satu produk peternakan yang dipilih orang karena mudah didapat dengan harga yang terjangkau. Sudaryani (2003) menyatakan bahwa kandungan gizinya merupakan perpaduan yang serasi dan seimbang antara protein, energi, vitamin, mineral dan air. Ditambahkan pula oleh Suprapti (2006) bahwa telur sangat baik dikonsumsi oleh anak-anak dalam masa penyembuhan dari suatu penyakit.

Kualitas telur menjadi perhatian penting untuk konsumen. Pada kenyataannya konsumen tidak suka dengan kuning telur yang berwarna pucat dan putih telur yang memiliki bercak merah seperti darah. Warna kuning telur biasanya menentukan telur yang diminati oleh konsumen dari segmen toko roti, kue atau jenis makanan lain yang memerlukan telur dengan warna kuning telur tertentu. Untuk itu, kualitas telur adalah hal penting yang harus diperhatikan dalam memenuhi kebutuhan protein masyarakat.

Ternak yang diberikan pakan yang berkualitas akan menghasilkan telur dengan kualitas yang baik pula sehingga sesuai dengan kebutuhan konsumen. Pemberian pakan yang berkualitas diharapkan mampu menghasilkan telurtelur yang berkualitas sehingga dapat memenuhi kebutuhan protein masyarakat.

Tomat adalah salah satu komoditas holtikultura yang tergolong tanaman musiman (berumur pendek), karena hanyaberproduksi satu kali dan setelah itu mati (Cahyono, 2005).Tomat merupakan komoditas penting dalam menunjang ketersediaan pangan dan kecukupan gizi masyarakat (Siagian, 2005). Selain memiliki rasa yang enak, buah tomat juga mengandung protein, karbohidrat, Kalsium, Fe, Magnesium, dan Vitamin C \pm $21 \mathrm{mg}$ serta Vitamin A, Fosfat, Kalium, dan lycopene (Siagian, 2005). 
Tomat juga mengandung likopen yang tinggi.Likopen merupakan pigmen yang menyebabkan tomat berwarna merah. Seperti halnya $\beta$-karoten, likopen termasuk kedalam golongan karotenoid.Kandungan likopen tepung tomat $(\mu \mathrm{g} / \mathrm{g}$ berat kering) 1001,91 atau setara dengan 1,0 mg/g berat kering (Sudjarwo, 2011). Penggunaan produk kaya karotenoid dalam ransum ayam petelur dapat menghasilkan telur rendah kolesterol. Kemampuan karotenoid ( $\beta$ karoten) dalam menurunkan kolesterol melalui dua cara yaitu (1) $\beta$ karoten bersifat antioksidan yang dapat mencegah teroksidasinya lipid, dan (2) $\beta$ karoten mampu menghambat kerja aktivitas enzim HMG CoA reduktase sehingga terbentuk mevalonat yang diperlukan untuk sintesis kolesterol (Einsenbard, 2005, Stes dan Stahl, 1995).

\section{Mohammad (2012) dalam} penelitian tepung tomat kering dapat digunakan sebagai pakan alternatif dalam pemberian pakan ayam petelur dengan tingkat inklusi hingga $190 \mathrm{~g} / \mathrm{kg}$ tanpa dampak negatif pada kinerja dan sifat kualitas telur.
Berdasarkan latar belakang yang telah dikemukakan diatas, maka dilakukan penelitian untuk mengetahui sejauh mana tepung tomat memberikan pengaruh terhadap kualitas internal telur ayam ras.

\section{MATERI DAN METODE PENELITIAN}

Materi yang digunakan dalam penelitian ini adalah ayam ras petelur berumur 36 minggu sebanyak 100 ekor. Kandang yang digunakan dalam penelitian ini adalah kandang battery dengan ukuran $37 \times 40 \times 30 \mathrm{~cm}$. Bahan pakan yang digunakan dalam penelitian ini yaitu jagung, dedak, tepung ikan, $\mathrm{CaCO}_{3}$, konsentrat $\mathrm{Cal} 9.36$ dan tepung tomat. Level tepung tomat yang diberikan pada masing-masing perlakuan yaitu :

\footnotetext{
$\mathrm{P} 0=$ ransum basal $100 \%$

$\mathrm{P} 1=$ ransum basal $98 \%+2 \%$ tepung tomat

$\mathrm{P} 2=$ ransum basal $96 \%+4 \%$ tepung tomat

$\mathrm{P} 3=$ ransum basal $94 \%+6 \%$ tepung tomat

$\mathrm{P} 4=$ ransum basal $92 \%+8 \%$ tepung tomat

Pakan yang digunakan dapat dilihat pada Tabel 1, 2, dan 3.
} 
Tabel 1. Komposisi Zat Gizi Tepung Tomat

\begin{tabular}{lr}
\hline Zat Gizi & Tepung Tomat \\
\hline Protein & $16,73^{*}$ \\
Lemak & $1,53^{*}$ \\
Serat kasar & $30,94^{*}$ \\
Calsium & $0,98^{*}$ \\
Phospor & $1,20^{*}$ \\
ME (Kkal) & $2416^{* *}$
\end{tabular}

*) Berdasarkan Hasil Analisa Balai Riset dan Standarisasi Industri Manado 2014

**) Hasil Analisa Laboratorium Ilmu dan Teknologi Pakan Fakultas Peternakan IPB 2014

Tabel 2. Komposisi Ransum Percobaan

\begin{tabular}{lccccc}
\hline \multirow{2}{*}{ Bahan Makanan } & \multicolumn{5}{c}{ Jumlah $(\%)$} \\
\cline { 2 - 6 } & $\mathrm{R}_{0}$ & $\mathrm{R}_{1}$ & $\mathrm{R}_{2}$ & $\mathrm{R}_{3}$ & $\mathrm{R}_{4}$ \\
\hline Ransum Basal & 100 & 98 & 96 & 94 & 92 \\
Tomat & 0 & 2 & 4 & 6 & 8 \\
\hline Total & 100 & 100 & 100 & 100 & 100 \\
\hline
\end{tabular}

Tabel 3. Komposisi Zat-zat Makanan Ransum Percobaan

\begin{tabular}{lccccc}
\hline \multirow{2}{*}{ Komposisi Zat-zat Makanan } & \multicolumn{5}{c}{ Persentase (\%) } \\
\cline { 2 - 6 } & $\mathrm{R}_{0}$ & $\mathrm{R}_{1}$ & $\mathrm{R}_{2}$ & $\mathrm{R}_{3}$ & $\mathrm{R}_{4}$ \\
\hline Protein & 17,49 & 17,47 & 17,45 & 17,44 & 17,42 \\
Lemak & 6,63 & 6,61 & 6,59 & 6,57 & 6,56 \\
Serat kasar & 4,31 & 5,41 & 6,5 & 7,24 & 8,69 \\
$\mathrm{Ca}$ & 2,76 & 2,75 & 2,69 & 2,66 & 2,56 \\
$\mathrm{P}$ & 1,42 & 1,16 & 1,42 & 1,41 & 1,40 \\
ME (Kkal) & 2766 & 2759 & 2752 & 2745 & 2738 \\
\hline
\end{tabular}

Keterangan : Hasil perhitungan berdasarkan Patrick and Schaaible (1982).

Pengujian kualitas internal telur yaitu dilakukan seminggu sekali pada setiap hari selasa pada minggu berjalan.Setiap perlakuan dan ulangan diambil satu butir telur untuk dianalisa. Pengambilan sampel dilakukan 3 minggu setelah ayam mendapat perlakuan. Sejumlah telur pada satu hari (Selasa) dikoleksi setiap minggu selama 8 minggu berjalan berturut-turut untuk dilakuan pemecahan pada keseokan harinya. Pengamatan karakteristik fisik adalah telur ditimbang, dicatat keadaan luarnya, keutuhan, kebersihan, warna, bentuk telur dan indeks telur, ratio, lebar dan panjang telur. 
Kemudian telur dipecahkan diatas meja kaca. Diukur tinggi putih dan tinggi kuning telur dengan kaliper digital.

Peubah yang dimati:

1. Indeks kuning telur (Muchtadi dan Sugiyono, 1992)

Index kuning telur

$$
=\frac{\text { tinggi kuning telur }}{\text { diameter kuning telur }}
$$

2. Warna kuning telur (North dan Bell, 1994)

Warna kuning telur diperoleh
dengan cara membandingkan warna
kuning telur dengan Roche Yolk Colour
Fan pada skala 1-15.

3. Haugh unit (Rodrigues et al, 2002)

$$
\begin{array}{ll}
\mathrm{HU} & =100 \log \mathrm{H} \\
& \text { dimana } \mathrm{H} \text { adalah }: \\
\mathrm{H} & =\mathrm{h}+7.685-1.7 \times \mathrm{W}^{0.37} \\
\mathrm{~h} & =\text { tinggi putih telur }(\mathrm{mm}) \\
\mathrm{W} & =\text { berat telur }(\mathrm{g})
\end{array}
$$

Analisa Data

$$
\text { Rancangan Acak Lengkap (RAL) }
$$
dengan menggunakan 5 perlakuan dan 5 ulangan. Data yang diperoleh dianalisis dengan menggunakan microsoft excel. Dilanjutkan dengan uji jarak berganda Duncan's (Steel and Torrie, 1994).

\section{HASIL DAN PEMBAHASAN}

Pengaruh penambahan tepung tomat terhadap kualitas internal telur dalam hal ini indeks kuning telur, warna kuning telur, dan haugh unitdapat dilihat pada Tabel 4.

\section{Pengaruh Perlakuan Terhadap Indeks Kuning Telur}

Berdasarkan data pada Tabel 4 dapat diketahui rata - rata indeks kuning telur yang diperoleh dari perlakuan $\mathrm{P}$, P1, P2, P3 dan P4 secara berturut turut adalah $0.45 \pm 0.02 ; 0.46 \pm 0.00 ; 0.45 \pm 0.00$, $0.45 \pm$ 0.00dan $0.46 \pm 0.00$. Untuk mengetahui pengaruh perlakuan, maka dilakukan analisis statistik.

Hasil analisis stastistik pada menunjukkan bahwa perlakuan penambahan tepung tomat dalam ransum tidak memberikan pengaruh nyata $(\mathrm{P}>$ 0,05) terhadap indeks kuning telur. Secara keseluruhan perlakuan P1 dan P4 memiliki indeks kuning telur lebih besar daripada perlakuan P0, P2, dan P3. Keadaan tersebut dimungkinkan karena protein pakan setiap perlakuan merupakan salah satu faktor yang mempengaruhi nilai indeks kuning telur, karena protein yang tersusun dalam zat makanan dalam pembentukkan membran vitelin dan khalaza yang berfungsi untuk menjaga kekokohan kuning telur saat proses pembentukkan telur. Kandungan protein dalam pakan tidak memiliki perbedaan yang jauh yakni P0 17,49; P1 17,47; P2 17,$45 ; \quad \mathrm{P} 3 \quad 17,44$ dan P4 17,42. 
Tabel 4. Pengaruh Perlakuan Terhadap Indeks Kuning, Warna Kuning, dan Haugh Unit

\begin{tabular}{cccc}
\hline \multirow{2}{*}{ Perlakuan } & \multicolumn{3}{c}{ Variabel } \\
\cline { 2 - 4 } & Indeks Kuning Telur & Warna Kuning Telur & Haugh Unit \\
\hline P0 & $0.45 \pm 0.02$ & $8.08 \pm 0.55^{\mathrm{a}}$ & $88.98 \pm 3.23$ \\
P1 & $0.46 \pm 0.00$ & $7.95 \pm 0.60^{\mathrm{a}}$ & $92.13 \pm 2.36$ \\
P2 & $0.45 \pm 0.00$ & $8.73 \pm 0.23^{\mathrm{b}}$ & $90.39 \pm 0.89$ \\
P3 & $0.45 \pm 0.00$ & $8.73 \pm 0.49^{\mathrm{b}}$ & $90.92 \pm 2.94$ \\
P4 & $0.46 \pm 0.00$ & $9.08 \pm 0.35^{\mathrm{b}}$ & $90.55 \pm 1.61$ \\
\hline
\end{tabular}

Keterangan : Superskrip yang berbeda pada baris yang sama menunjukkan pengaruh berbeda sangat nyata $(\mathrm{P}<0,01)$

Komala (2008) menyatakan bahwa protein merupakan komponen terbesar penyusun putih dan kuning telur selain air dan lemak ( pada kuning telur).

Besar kecilnya indeks kuning telur juga dapat dipengaruhi oleh level kandungan protein dalam pakan. Beberapa penelitian melaporkan bahwa pemanfaatan tepung daun papaya dalam peningkatan produksi dan kualitas telur ayam sentul menghasilkan nilai indeks kuning telur yang tidak berbeda nyata ( $\mathrm{P}>0,05)$ dengan kisaran indeks kuning telur $0,44-$ 0,46 (Widyastuti, 2009). Keadaan kuning telur yang cembung dan kokoh ditentukan oleh kekuatan dan keadaan membran vitelin dan khalaza yang terbentuk oleh pengaruh protein pakan dalam mempertahankan kondisi kuning terbentuk oleh pengaruh protein pakan dalam mempertahankan kondisi kuning telur (Bell dan Weaver, 2002; Yamamoto et al., 2007). Atik (2010) menjelaskan bahwa semakin tinggi kandungan protein dan lemak dalam pakan maka semakin tinggi indeks kuning telur.

\section{Pengaruh Perlakuan Terhadap Warna Kuning Telur}

Berdasarkan data pada Tabel 4 dapat diketahui rata - rata warna kuning telur yang diperoleh dari perlakuan P0, P1, P2, P3 dan P4 secara berturut turut adalah $8.08 \pm 0.55 ; 7.95 \pm 0.60 ; 8.73 \pm 0.23$; $8.73 \pm 0.49$ dan $9.08 \pm 0.35$. Untuk mengetahui pengaruh perlakuan, maka dilakukan analisis statistik.

$\begin{array}{rrr}\text { Hasil } & \text { analisis } & \text { stastistik } \\ \text { menunjukkan } & \text { bahwa } & \text { perlakuan }\end{array}$
penambahan tepung tomat dalam ransum memberikan pengaruh yang berbeda sangat nyata $(\mathrm{P}<0,01)$ terhadap warna kuning telur. Terlihat pada masing-masing perlakuan bahwa penambahan tepung tomat pada level $8 \%$ dalam ransum dapat meningkatkan warna kuning telur. 


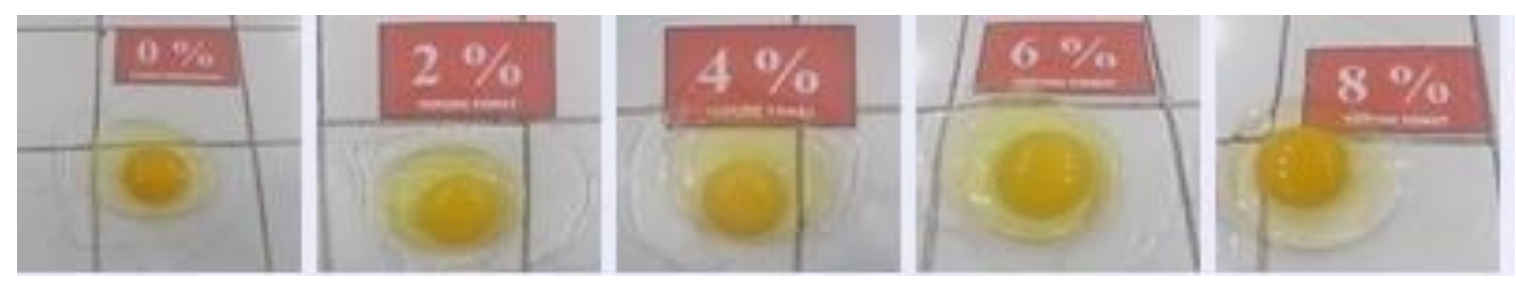

Gambar 1: Penampakan Warna Kuning Telur Hasil Penelitian

Hal ini disebabkan dalam buah tomat terkandung likopen.Seperti halnya $\beta$ karoten, likopen termasuk kedalam golongan karotenoid.

Beberapa hasil penelitian menunjukkan bahwa pigmen karotenoid dapat mempengaruhi warna kuning telur. Kang et al (2003) melaporkan bahwa penambahan likopen sebagai sumber karoten memberikan pengaruh yang nyata terhadap warna kuning telur. Ditambahkan pula oleh Dotas et al (2000) yang melaporkan bahwa penambahan tomat kering tidak memberikan perbedaan yang nyata terhadap produksi telur, konsumsi pakan, bobot telur, tetapi memberikan perbedaan pengaruh terhadap warna kuning telur. Warna kuning telur dipengaruhi oleh zat-zat yang terkandung dalam pakan seperti xanthofil, betakaroten, klorofil dan cytosan (Argo, 2013). Yuwanta (2010) mengemukakan warna kuning telur ditentukan oleh kandungan $\beta$ karoten yang terdapat pada kuning telur. Unggas yang mengkonsumsi pigmen karotenoid lebih tinggi akan menghasilkan intensitas warna kuning telur yang lebih tinggi. Pigmen pemberian warna kuning telur yang ada dalam pakan secara fisiologis akan diserap oleh organ pencernaan usus halus dan disebarkan ke organ target yang membutuhkan (Sahara, 2011).

Perlakuan yang memberikan pengaruh yang berbeda sangat nyata dilakukan pengujian lebih lanjut yaitu dengan uji jarak berganda Duncan. Berdasarkan hasil analisa uji lanjut menunjukkan bahwa pemberian tepung tomat pada level $8 \%$ memberikan skor warna kuning yang lebih tinggi. Sudaryani (2003) menyatakan bahwa warna kuning yang baik yaitu berkisar antara 9,00 12,00 .

\section{Pengaruh Perlakuan Terhadap Haugh unit}

Berdasarkan data pada Tabel 4 dapat diketahui rata - rata warna kuning telur yang diperoleh dari perlakuan P0, P1, P2, P3 dan P4 secara berturut turut adalah $\quad 88.98 \pm 3.23 ; \quad 92.13 \pm 2.36$; $90.39 \pm 0.89 ; \quad 90.92 \pm 2.94$ dan $90.55 \pm 1.61$. 
Untuk mengetahui pengaruh perlakuan, maka dilakukan analisis statistik.

$$
\text { Hasil analisis statistik }
$$

menunjukkan bahwa penambahan tepung tomat dalam ransum tidak memberikan pengaruh nyata $(\mathrm{P}>0,05)$ terhadap warna kuning telur. Kualitas telur yang meliputi tinggi putih telur dan nilai haugh unit dipengaruhi oleh protein pakan, imbangan lisin atau metionin dan interaksinya (Atik, 2010). Ditambahkan pula oleh Tuti (2009) bahwa berat telur dan kekuatan putih telur yang tidak berbeda nyata akan menghasilkan nilai haugh unit yang tidak berbeda nyata pula, karena besar kecilnya nilai haugh unit tergantung pada berat telur dan tinggi albumen.

Nilai rata-rata yang didapatkan pada penelitian menunjukkan bahwa nilai haugh unit yang diperoleh tergolong dalam kualitas AA. Hal ini sesuai dengan Sudaryani (2003) yang menyatakan bahwa nilai haugh unit yang normal berkisar $>72$ digolongkan kedalam kualitas AA.

\section{KESIMPULAN}

Penambahan tepung tomat dalam pakan tidak memberikan pengaruh terhadap indeks kuning telur dan Haugh unit, namun memberikan pengaruh terhadap kuning telur ayam ras petelur.

\section{DAFTAR PUSTAKA}

Atik, P. 2010. Pengaruh Penambahan Tepung Keong Mas (Pomacea canaliculata Lamarck) Dalam Ransum Terhadap Kualitas Telur Itik. Fakultas Pertanian Universitas Sebelas Maret, Surakarta.

Argo. L. B, Trirtiarti dan I. Mangisah, 2013. Kualitas Telur Ayam Arab Petelur Fase I Dengan Berbagai Level Azolla microphylla.Animal Agricultural Journal, Vol. 2. No. 1, 2013, p 445-457. Online at: http://ejournal-

sl.undip.ac.id./index.php/aaj.

Cahyono. B. 2005. Cara Meningkatkan Budidaya Ayam Ras Pedaging. Penerbit Pustaka Nusantara. Yogyakarta.

Dotas, D. S. Zamanidis; N. J. Balios. 2000. Effect of Dried Tomato Pulp On The Performance and Egg Traits of Laying Hens. British Poultry Science.Volume 40, Issue 05 December 2000, 695-697 Animal Physiology Embriology, Meat and Poultry.

Einsenbard.2005. Toxilogical Evaluation of RedMold Rice.DFV-Senate Comision on Food Savety.

Kang, D. K., S. I. Kim, C. H. Cho, Y. H. Yim, \& H. S. Kim. 2003. Use of lycopene, Anantioxidant carotenoid, in laying hens for egg yolk pigmentation. Asian-Aust. J. Anim. Sci. 16 (12): $1799-1803$. 
Komala, I. 2008. Kandungan Gizi Produk Peternakan. Student Master Animal Science, Fakultas. Agricultutre-UPM.

Medhy, A. 2008.Kandungan Gizi Telur. http://ayumedhywordpress.com/2008/ 12/ubi-jalar-kayu-zat-dan-serat. Diakses pada 12 Desember 2014.

Mohammad H. S, Shabab Ghazi, Reza Mahdavi and Omid Mozafari. 2012. Effects of different levels of dried tomato pomace on performance, egg quality and serim metabolites of laying hens. African journal of biotechnology Vol. 11(87), pp 1537315379.

Muchtadi TR, Sugiyono. 1992. Ilmu Pengetahuan Bahan Pangan. Petunjuk Laboratorium. Departemen Pendidikan dan Kebudayaan Direktorat Jenderal Pendidikan Tinggi Pusat Antar Universitas Pangan dan Gizi, Institut Pertanian Bogor.

North, M.O. \& D. D. Bell. 1992. Commercial Chicken Production Manual. $4^{\text {th }}$ Edition. An AVI Book Published by Van Nostrand Reinhold, NewYork. Opena, R. T., Van der Vossen. $1997 . \quad$ Lycopension Esculentum Mill. Dalam Siemonsma dan K. Piluek (eds) Plant Resources of South East Asia. Puddock Scientific Publisher Waginingen Netherlands. Pp 199-205.

Rodriguez, L. V., J. H. Haro, E. M. Barrera, M. E. S. Oporta, M. G. Alcoria and C. G. Bojalil. 2002. Citric and Microbial Phytase Relative to Productive Performance and Phosporus, Calcium and Nitrogen Excretion In Laying Hens. Tec Pecu. Mex. 40 (2) ; 169 - 180.
Sahara, E. 2011.Penggunaan Kepala Udang Sebagai Sumber Pigmen dan Katin dalam Pakan Ternak.

Siagian, A 2005. Lycopene Sexwa Fitokimia Pada Tomat dan Semangka.Oktober 2005.

Steel RGD, Torrie JH. 1994. Prinsip dan prosedur Statistika (Suatu Pendekatan Biometrik). Terjemahan : Bamabang Sumantri. Jakarta: Gramedia Pustaka Umum.

Sudaryani, T. dan H. Santoso. 2003. Pembibitan Ayam Ras. Cetakan keVII. Penebar Swadaya, Jakarta.

Sudjarwo. E. 2011. Pemanfaatan Tepung Tomat Sebagai Imbuhan Pakan Terhadap Penampilan Reproduksi Itik Mojosari. Universitas Brawijaya. Malang.

Suprapti, L. 2006. Pengawetan Telur Asin, Tepung Telur, dan Telur Beku. Kanisius.Yogyakarta.

Widyastuti, T. 2009. Pemanfaatan Tepung Daun Pepaya (Carica papaya.L L ess) Dalam Upaya Penngkatan Produksi dan Kualitas Telur Sentul. J. Agroland 16 (3) : 268 - 273, September 2009 ISSN : 0854 - 64 IX. Fakultas Peternakan Universitas Padjajaran.

Yamamoto, T., L.R. Juneja, H. Hatta, and M. Kim. 2007. Hen Eggs : Basic and Applied Science. University of Alberta, Canada.

Yuwanta,T. 2010. Telur Dan Kualitas Telur. Gadjah Mada University Press, Yogyakarta. 